\title{
Field of screams: difficulty and ethnographic fieldwork
}

\author{
By Amy Pollard (Cambridge University)
}

Ethnographic fieldwork can be a time of intense vulnerability for $\mathrm{PhD}$ students. Often alone and in an unfamiliar context, they may face challenges that their pre-fieldwork training has done little to prepare them for. This study seeks to document some of the difficulties that $\mathrm{PhD}$ anthropologists at three UK universities have faced. It describes a range of feelings as experienced by 16 interviewees: alone, ashamed, bereaved, betrayed, depressed, desperate, disappointed, disturbed, embarrassed, fearful, frustrated, guilty, harassed, homeless, paranoid, regretful, silenced, stressed, trapped, uncomfortable, unprepared, unsupported, and unwell. The paper concludes with a set of questions for prospective fieldworkers, a reflection on the dilemmas faced by supervisors and university departments, and a proposal for action.

This small study was inspired by my own difficulties and those of my friends during our PhD fieldwork. Were these difficulties down to our particular bad luck and bad judgement, or did other $\mathrm{PhD}$ anthropologists have similar experiences? Were our experiences particular to our academic department, or were they shared by those at other universities? Hoping to find out, I interviewed $16 \mathrm{PhD}$ students from three different anthropology departments in the UK.

Fourteen of these students were post-fieldwork, one was mid-fieldwork, and another was in the final stages of preparation before leaving for the field. Two of the "students" were actually post-viva (i.e. they had already undergone the thesis defence), but had completed their PhDs within the last year. Interviewees volunteered in response to a general email sent to anthropology $\mathrm{PhD}$ students, and also through snowball sampling. The interviews took place in person, by email and by phone, in October and November 2008. Interviewees have been anonymised and some details have been changed. All interviewees have checked drafts of this study and have corrected, improved and verified the ways their experiences are described. Whilst I would not claim that descriptions are therefore "truthful", I hope they are an accurate snapshot of how students were thinking and feeling at this particular moment in their lives.

In the years prior to this I had spoken to dozens of anthropologists about their fieldwork. I thought I knew what kinds of things people might say to me in interviews. I was quite taken aback by what actually emerged.

This document is intended as a teaching aid for $\mathrm{PhD}$ students, and also as a provocation for supervisors and Social Anthropology departments in the UK. The evidence of this study, albeit limited in its scope, suggests that pre-fieldwork training courses for $\mathrm{PhD}$ anthropologists may be inadequate. It suggests that supervisors cannot and do not always provide appropriate support. It suggests that $\mathrm{PhD}$ students should be prepared for a wide range of difficulties in the field, and that a significant 
number may face difficulties that they never anticipated, and which no academic examination will have tested their ability to cope with.

The study is critical of university departments, of supervisors and of $\mathrm{PhD}$ students. However, it has no intent or capacity to direct blame towards any of these parties. The descriptions of students give only "one side of the story" - and this story itself changes as people continually reflect on their experiences and carry on with their lives. This study seeks to describe the difficult feelings that $\mathrm{PhD}$ anthropologists have had on fieldwork, and suggest ways that departments, supervisors and students themselves might become better able to cope with them. Whilst it may be possible for departments to assist with some of the issues involved, many lie beyond what might reasonably be expected of them - and there may be opportunities for individuals throughout the academic system to give and receive better support.

Data was coded around 24 feelings: alone, ashamed, bereaved, betrayed, depressed, desperate, disappointed, disturbed, embarrassed, fearful, frustrated, guilty, harassed, homeless, paranoid, regretful, silenced, stressed, trapped, uncomfortable, unprepared, unsupported and unwell. I have fragmented the accounts in this way partly as an anonymising strategy, and partly to suggest that whilst their feelings are unique and complex, the experiences of $\mathrm{PhD}$ anthropologists have enough in common that we might have a conversation about them. It is conversation, above all, that this study aims to promote.

The study concludes in three parts. The first part offers questions for PhD students. The second outlines dilemmas that may be faced by supervisors - "support versus independence", "autonomy versus guidance", "authority versus communication"; and also dilemmas that may be faced by academic departments - "preparation versus flexibility", "theory versus practice", "requirements versus needs". Finally, the study offers a recommendation for action.

I will begin by outlining some counterfactual evidence.

\section{Counterfactual}

The email that I sent out at the start of the study explicitly asked for interviewees who would be willing to discuss "difficulty" in fieldwork. Students may have self-selected on this basis and therefore have had more "difficult" fieldwork experiences than a random sample of $\mathrm{PhD}$ students. On the other hand, there were some students who initially wished to participate in the study but who were still in the midst of postfieldwork trauma, and found their experiences too difficult to relay in interview or in text.

Not everyone had a horrible time on fieldwork, and even those who reported serious difficulties said they also had many good experiences. "I've only told you the bad stuff," said Euan, "I've loved that region for years... [it] has always amazed me." One student said that when reading their experiences back in a draft of this study, they felt they had not told me enough about the positive aspects of their fieldwork.

Interviews were influenced by the techniques of active listening that I learned as a volunteer at Samaritans (a UK charity that offers a telephone support line). ${ }^{1}$ I hoped to

\footnotetext{
${ }^{1}$ I wrote most of the study from the Samaritans centre in Cambridge, finding it useful to be in a supportive environment when working with the data.
} 
explore fieldwork difficulty in an empathetic and supportive way. The interviews therefore steered into difficulty, rather than aiming to capture fieldwork experience as a whole. When commenting on the first draft, many students moderated and tempered the ways they described their experiences when interviewed. They also reflected on the accounts of the other interviewees.

Some students experienced difficulties in the field, but managed to deal with them confidently. Some people felt they were able to accept the limitations of what they could do on fieldwork, and were at peace with the decisions they had made over their life and work.

Some people said that fieldwork was actually much easier than they had anticipated. Telma, having been worried about her fieldwork before she embarked on it, actually found that it went well. She suggested that it was a mistake to concentrate too much on difficulties in the field: "Fieldwork is fetishised. For me, being out there wasn't as difficult as returning [here, to the UK]."

A number of people found "the return" more difficult than fieldwork itself. Akanksha, for example, found herself isolated from other people in her year group. Coupled with difficulties of finding accommodation and settling back into life in the UK, this was a more challenging time than her fieldwork itself. Another person said that she had not realised until she returned to the UK how much of a toll her fieldwork had taken on her: "I had all the symptoms of post-traumatic stress disorder."

There were reports of some brilliant acts of teaching. Before she left for fieldwork, Poppy's supervisors had set her an extra assignment: to write five pages on the worst case scenario, and how she would cope with it. She worked together with her supervisor and second supervisor to construct an emergency plan, whereby with one phone call she could set in motion a telephone tree - including her parents, lawyers, friends and members of the department - and access a range of help. Poppy used the telephone tree when she was confronted by the state intelligence services, who wanted to investigate her research activities. She discussed the investigation with her supervisors whilst in the field, and they ensured that if the intelligence services phoned the main university phone number, the switchboard would immediately put them through to one of them. Poppy was given the contact details of a local lawyer, who prepared her for the interrogation process. She endured a three-day interrogation at a police station: "I did get nervous but it wasn't that bad. I just kept reminding myself again that I wasn't doing anything wrong." Afterwards, Poppy took herself on a short holiday and allowed herself to relax. "My supervisors made all the difference. My experience was very special and not at all representative... nothing like that was part of (the pre-fieldwork) course."

Several students said their supervisors had been helpful and supportive. Hafsah, for example, described how her supervisor had supported and empowered her: "She has a very good ear and she's good at listening... she has a capacity to help you think for yourself." Others described having had useful classes on managing their supervisors, interviewing, publishing and other professional skills: "They said, just spend half an hour every day emailing someone and telling them about your project. That's very important for me because I know I need to get my networks strong."

Several students described how the difficulties they had in the field were actually very good for their projects. Maria found she was able to interview people in a different way, having become intimate with them through her difficulties: "It engendered new 
webs of relationships which wouldn't have happened otherwise. There's a kind of openness which comes of that kind of thing." Ruth said, "It was the worst thing that has ever happened to me, but I'm incredibly grateful for that experience. You have an incredible sense of freedom after surviving something like that... and it really was the moment when my thesis began."

\section{Alone}

Almost all interviewees described feeling alone during their fieldwork. Many were far from their friends and family, and had little access to email or phones. Internet access was very important for many students, and it was described by one person as "like a life-line".

Even those doing fieldwork in their "home" countries described their feeling of isolation. They described how the differences between themselves and their informants made them feel alienated. Phuong's father lived 15 hours away from her fieldsite, and although she spoke a common language with her informants, she had no one to talk to about her research: "You feel like you can't talk about your research to anyone... sometimes it's useful just to put your mind at rest. They don't understand what you are doing here." Akanksha, who had worked in her fieldsite for several years prior to fieldwork, said having no one to discuss her research with sometimes made her feel very lonely. Xiu Mei, despite doing the first part of her fieldwork with extended family, described moments of feeling isolated.

Some students had close contact with their supervisors, maintaining regular email contact and getting responses within a day or two. Other students said that they had almost no correspondence with them during fieldwork.

One student suggested there was a pervasive ideology around difficulty in anthropology: "There's a macho sense of doing fieldwork... you go through hardship and struggle and you have to get through it." She had become ill with overwork, and felt that her supervisor had not helped her to feel able to slow down. Her informants and friends in the field did not know how she was in her normal life, and so did not realise that her condition was serious. Her decision to stop fieldwork for health reasons could be taken by her alone: "I was the only person who could make that decision." Others described having clashes with their supervisors over the focus of their research: "She always tries to get me to write about her interests, which are not my interests!"

For some students, the need to be able to make decisions about their fieldwork led them to seek separateness from others. Sue described how she felt under pressure to communicate with her boyfriend, and that they had many arguments (especially in the initial stages) when living together in the field: "He tried to help with strategies for meeting people, and I'd say, 'no, that's not ethical', or that it wouldn't work." Looking back, she said perhaps she had been taking her feelings of frustration and being out-of-depth out on him. Sue was accustomed to being separated from her family, and was able to talk by email and phone as she did in her non-fieldwork life: "Communication (from my fieldsite) carried on as it did from anywhere."

Students from every university department described having little contact with other members of the PhD cohort during fieldwork. Some said that the lack of contact during fieldwork was due to lack of access to internet and phones, whilst others said that they did not feel close enough to their peers to talk to them about their 
experiences in the field, or felt them to be too competitive. Maria described how despite having made friendships in her pre-fieldwork year, she could not be in contact with others during fieldwork itself: "I remember... a shared sense of "we are all on our own in this' - and that we wanted to maintain it."

Maria sought solitude in other ways too, living alone and separating herself from certain relationships in the field. "I remember that I did turn to isolation and I did it very deliberately. It carried on for an entire year." She described this period as the loneliest she had ever been. Like several of the students, she had lost the person she thought she would marry through fieldwork (see below under "Bereaved").

Many students felt alone in the ways that fieldwork was changing them. Several people described how their time in the field eroded, reshaped or transformed their sense of self. Whilst some felt that their "new" self was an improvement, many described the process whereby it had emerged as a traumatic and isolating experience. Telma found that coming back from the field was the moment when the shift in her personality became evident: "You've changed and you don't know how."

\section{Ashamed}

A large number of students felt profound shame over their sense of failure in the field. "I just remember feeling absolutely fucking worthless," said one person, "like what I was doing was never what you should be doing on fieldwork". Several students described a mental division between the activities they should be doing on fieldwork, and those which were not really part of it. Tracey described how she was "obsessed with all the things I had to do as a language student... the whole time I was busy and [yet] I was aware that my fieldwork wasn't even starting". Abiona felt that she should press on with fieldwork even when her body was weak: "As soon as I felt a little bit better I'd rush off. I felt that if I didn't spend the whole day at the [fieldsite] I was a failure. I'd chastise myself if I only did a couple of hours, that I was not doing real fieldwork."

The sense of shame was particularly acute for those suffering mental health problems. Maria described how her informants noticed her depression, and told her it would sabotage her fieldwork: "[My informant] said to me - 'You're never going to be received by people if you are like this... If you are not [Maria] you are never going to be received by people'." She interpreted this to mean that she was not sufficiently herself to be a good fieldworker, and cursed her inability to break out of her negative emotions: "I thought, this isn't productive - I shouldn't be feeling this much." Ruth's informants were also the first to notice something was really wrong with her. When she was suffering from stress-induced psychosis, she sent desperate emails seeking help: "I still get flashbacks of some of the things I wrote." She described how she knew she needed to go home, but did not trust anyone to help her get there: "In the end my dad had to fly out to take me home."

For some, going home early was a source of great shame. Tracey described how she felt she had failed when told by her supervisor to return and revise her research proposal. Despite saying she "had no idea what I was doing", returning home felt like a loss of face. She says now that returning home at this stage was critical to making her project a success. Several students remarked that they felt if they did their fieldwork in sections (returning home every few months) they were not doing fieldwork "properly". One person realised that she was becoming psychologically 
affected by her experiences, and came home from the field one month early. She felt supported in this decision by her supervisors.

Several students said that they felt shame when pursuing activities in the field that they thought their departments would disapprove of. Euan felt that, in anthropology generally, there might be disapproval of an anthropological researcher hanging out with other foreigners whilst on fieldwork, or relaxing in "ex-pat" places. He described the ex-pat friends he made as "indispensible to my mental health", and he suggested that hanging out with such people was a good way to meet informants: "It's much easier to know if they are dodgy or not [because you speak the same language], and then you can be more sure that the people you meet through them are not dodgy."

\section{Bereaved}

Students experienced many kinds of loss during their fieldwork. Several had a death in the family during the fieldwork process, and some felt that their studies undermined their grieving process. Others were working in fieldsites where there was a lot of death, and witnessed the deaths of some of their informants.

A high proportion of students lost romantic relationships over the course of fieldwork. Some said that the pressure of going away had forced an ending. Others felt betrayed by their partners, or felt ashamed of the betrayals they were responsible for themselves. Some made relationships in the field, only to lose them when they left. They often had to cope with this without support from their friends and family. Maria described how romantic loss disabled her engagement with the field: "I felt like I'd left most of my limbs in Britain, and I wasn't willing to detach myself at all."

Other relationships survived fieldwork itself, but broke down when students returned to the UK. Coupled with everything else she had been through, at the time, this was too much for Hafsah: "I thought I could at least rely on my boyfriend, but no. It was very dramatic. I was thinking I don't want to live anymore - that this world is completely crap and there's nothing I can rely on. It was like there was nothing in the world to hold me." When she first described this to me Hafsah talked about how she felt well recovered from this now. Afterwards however, and reading it back in text, she said she realised how much the break-up of her relationship was still affecting her.

Several students said they thought a lot about death during the fieldwork process. One person made a will, and two people had suicidal thoughts. Peter described how he had a lot of nightmares about death before he left for the field. "I felt like I was dying in some way. I look back now and I think it was about losing my life - my life here." He described how pre-fieldwork students were often naive: "People don't understand that they will lose their life, and they will never get it back. You can't just come home... relationships will have changed, marriages will have broken up. You leave and you can never really come back." The major exceptions to this, he suggested, were "people who did fieldwork in [their own countries] and basically kept their lives. A lot of them have quite indifferent experiences." (Peter was speaking in an ordinary conversation, not a formal interview, and has kindly allowed these remarks to be reproduced.) 


\section{Betrayed}

Betrayal was a difficult feeling for students, and one that they were often hesitant to name. Several students had experienced moments during fieldwork when a previously trusted informant acted in such a way as to abuse or endanger them. Euan thought he had built up a good relationship with one man, even lending him his house for a month. He described how the man suddenly "became a different person... manipulative, bullying... a real prick. It really freaked me out." Euan described how although this experience was unpleasant at the time, it had helped him understand his fieldwork context better.

A number of students told stories second-hand of $\mathrm{PhD}$ anthropologists facing rape and sexual assault in the field, which cannot be relayed here. Ruth described how, a week before her psychosis, one of her previously trusted informants had leapt on her at the end of the night. "I couldn't afford to lose him as an informant at that point... I couldn't handle the stress of making a fuss about it. It was easier just to let him do whatever." She described how whilst she maintained good relations with the man during fieldwork, she has since excluded him from her ethnographic writing: "I needed him in the field, but I don't need him in writing up. I don't want him to have any rights to comment on my work." She felt this act would be seen by others as evidence of her academic inadequacy: "There's this idea that 'all that is understood is forgiven'... and that we have to forgive our informants for everything they do, otherwise we haven't understood the field properly."

Connected to feelings of shame (see above under "Ashamed"), some students reported feeling that they had betrayed themselves. "I felt very betrayed by my own failure to reach out to others," described Maria. Ruth said: "I just prioritised my work and abandoned my body."

\section{Depressed}

Several students reported feeling seriously depressed during their fieldwork. Tracey described how she would try to sleep all day, to see if she would feel better. It was very unlike her: "I've never been that sort of person... I ate like nothing before... I was so sad." Xiu Mei also described trying to sleep all day, and said that her family had been critical in forcing her to stay active. Ruth said that at one stage she could not imagine carrying on with fieldwork: "I just couldn't see a way forward - not with this or with anything. I would look at people doing normal, everyday things and wonder how on earth it was possible."

Students criticised themselves for feeling depressed, and were criticised by others. Several students said their informants told them not to feel so sorry for themselves, saying that they were not going to be able to carry out research if they did not cheer up. Maria described how depression stopped her from feeling really interested in her fieldwork site for 12 months. Looking back, she was disappointed at the "very mechanical way" in which she had done this fieldwork, and resented the mental turmoil which had precipitated her depression. She only began to feel excited and curious about her fieldsite in the last six months of fieldwork, and described her depression as a "deeply destructive choice". Seeking to take responsibility for what happened, she ventured that "your grief and your depression is something you strive to hold onto because it is a source of meaning... I had deliberately embraced it as a way of pegging me to something." This was a reaction to the feeling that she was "in 
no way contained" whilst she was in the field. She had been given an enthusiastic endorsement of her research in her pre-fieldwork viva (oral defence), and looking back, felt that she had been given more autonomy than she could handle.

\section{Desperate}

Sue found it difficult to get informants to talk to her. People would not introduce her to others in the field because it was too much responsibility for them. "They got more helpful the more desperate I got... I had to play on the desperation."

\section{Disappointed}

Some students were disappointed that their fieldwork did not go to plan. Phuong had a very clear idea of what she was looking for, and did not find it. She was disappointed, but she did find something "less exciting" she could work with. Tracey had to go through a laborious research ethics clearance process to gain access to her fieldsite. "It was the hardest thing I've ever had to do... and they turned it down."

Several students felt disappointed by their supervisors. One person described how her supervisor set her up with an entirely inappropriate initial contact in the field, who was not able to relate to her as a young white woman: "It was so stupid [of the supervisor] not to foresee that." Another person described how their supervisor failed to reply to emails, and even neglected to complete a piece of paperwork which resulted in the student's funding being suspended for several months. One supervisor refused a direct request for help in an emergency situation, much to the distress of the student: "I don't know why... I mean, I understand that you have to make your own decisions in the field, but I really needed her."

\section{Disturbed}

A large number of students reported sleeping badly during fieldwork. They had "horrible dreams", "amazing nightmares", and were still waking up with palpitations. Kevser slept badly because she was not confident that her house was secure. During her fieldwork a neighbour had been robbed at knifepoint and threatened with rape. She was not able to relax even after leaving the field: "When I came back it took me a long time to learn how to sleep again."

Several students found that their experiences in the field disturbed their sense of what they could believe. Maria felt that she "couldn't locate myself ethically at all... I didn't know where I belonged and who I believed in". This undermined her ability to ethically judge things that had happened to her in the field. "I wasn't able to judge if [he] had wronged me or not... or whether I had done the right thing." Another student, whose research involved sorcery and magic, found themselves finding it difficult to tell what was real and what was not.

Sue also questioned herself in the field. She was harassed by one of her informants, who had, he said, fallen in love with her. Describing her anger and disappointment at his behaviour, she spoke of how she had attempted to emphasise friendship with him from the beginning. Although she was sure, looking back, that there was nothing else she could have done, at the time she questioned whether she was handling the situation appropriately. 


\section{Embarrassed}

Poppy was shot with a rubber coated bullet in her behind. "It sounds like a big deal but it wasn't really," she said; "it's quite common in [my fieldsite]... I was just embarrassed because it was in my behind... I had to lie on my tummy with my arse exposed." She described how she was not scared at the time, only afterwards when she was telling her parents about it. "It was strange, [people in the fieldsite] shoot so much that it becomes sort of abstract... you don't think bullets can actually hit you."

\section{Fearful}

The physical safety of students was a major concern for their families. Kevser described how her mother was terrified about her safety before she started fieldwork, and demanded a meeting with her supervisor. Kevser's supervisor made it clear that he would not be held responsible for anything that happened, and that Kevser was making her own decisions as an adult. "Mum was not very happy."

When she reached the field, Kevser was told it was not safe to walk outside, or even to stay in a hotel room which was on the ground floor. "I was petrified... so unhappy." As time went on, she attempted to find out whether these fears were justified. "I was told by everyone not to go out after $6: 30 \ldots$ but it's very difficult to tell what the reality of the situation is." She had initially written the cost of a car into her research budget, but had been advised to remove it by a member of the department, on grounds that it would appear excessive to her funding body. "It was so ridiculous not having a car. It was like having a curfew and being locked up every night. It really affected how I could do fieldwork. I wasn't able to go to [the fieldsite] at night, never able to go out socially with [informants] because I couldn't get there and back."

Physical safety was a particular issue for female research students. Several described how they felt very visible, and were vulnerable in public no matter how much they covered up their bodies. Hafsah described how she was almost kidnapped. "He was driving in the opposite direction... he put his hand on my lap and I just jumped out of the moving taxi. It was horrible. The greatest fear of my life." Two other people felt that they had been in life-threatening situations whilst on fieldwork.

Other students described how they were fearful of losing their data. One had a "moment of crisis" when her computer crashed. The process of getting the problem dealt with abroad, speaking in her second language was "terrifying... I thought I might have lost everything". Thankfully, the data was recovered. Several students had good reason to fear that their computers would be seized by the secret police, or by another state authority.

Euan was fearful of powerful forces in his fieldsite turning against him, suppressing or terminating his work. "The Government is super, super sensitive and wants you to go through the right channels. But if you go through these channels you'll have to work with a Government Minder and you'll be controlled. I thought I'd just register as a student and do it on the sly." This covert work was a great strain: "Everything was undercover. I was paranoid from the start, and I lived in constant fear of being kicked out. In some ways I wished it."

Abiona was so fearful of failing at fieldwork that she ignored the warning signs from her body that she was working too hard. Her supervisor had told her that excellence in examinations was no mark of academic ability - anthropologists had to prove 
themselves through fieldwork. "I was so terrified of failing the test of fieldwork, that I couldn't admit to myself that something was really wrong." Phuong was relatively relaxed about the idea that her fieldwork would be limited, but still had moments of worry about whether it was sufficient. "Do I have enough information? Should I stay in this place or should I move on? There are a lot of strategic questions and you aren't really prepared for that. You don't have anyone to talk to."

The political sensitivity of Euan's work meant that his would-be informants were very frightened of him. "The first time [my translator and I] went to the temple there were these hot-headed radicals who thought I was a reporter. They started shouting and screaming, saying 'get out, get out'... [During another fieldwork activity] I could see the secret police photographing me from the other side of the road. Then the head of the temple saw me and he was terrified. The whole congregation was terrified. After that I said, no more temples."

\section{Frustrated}

Experiences such as the above led to feelings of frustration amongst students. Several people reported that political or personal issues meant that they were not able to gather certain kinds of data. Sue's informants rarely invited her to join them for social occasions because she had a boyfriend. Whilst being in a relationship was in some ways useful, making her feel more "safe" in the field, it meant she missed out on some opportunities for gathering data. Phuong described feeling frustrated when her informants demanded her possessions and took them without saying thank you. "I found that frustrating, almost exasperating. I felt they were taking advantage [of me]." Whilst she defended their behaviour, saying "I'd do the same if I was them", their actions made her feel alienated from them: "It puts you back in your place as a foreigner... it made me feel isolated."

Pippa was very frustrated at the difficulties of getting access to her informants. Although the women she wanted to work with were actually very welcoming of her research, the institutions around them were resistant to Pippa's project. Constantly having to justify and account for her anthropological work to these authorities was exasperating: "They were quite rude... questioning my thesis and diminishing my skills." She eventually managed to win them over, and now faced a dilemma about how to describe her experiences: "I don't know whether to write about it or not, because in the end they helped me."

\section{Guilty}

A number of students felt guilty for letting down their friends, family and lovers whilst they were on fieldwork. Maria had flown home to Britain after a few months of fieldwork to be bridesmaid at a friend's wedding. "I turned up at this little stone church and wept all over this friend who was about to be married. I was deeply embarrassed and completely unscrewed... I performed very badly as a bridesmaid." Rozalina's grandfather had died a few days before she had to hand in her fieldwork proposal. "It was a real time of fuck fuck fuck. I was very personally upset... I drove down for the funeral, and I didn't do a reading like all the other grandchildren did. My mother said 'don't push yourself too much', but I felt like I hadn't done it properly; like people didn't think I was grieving. The vicar didn't realise I was a grandchild." 
Ruth described how she was away on fieldwork when her best friend broke up from her boyfriend. "Usually, I would have been able to talk to her about it all. I'm not saying I could have made everything better, but it wasn't good that I was away. She completely fell apart and I did feel like I'd let her down."

During Rozalina's fieldwork, her sister suffered mental health problems and was sectioned. Rozalina was having serious problems in the field at the time, but did not feel she could ask for help from her family. "I didn't feel I could take up the space of the needy child. I was fine. I was fine. I just didn't know what I was doing."

Euan felt guilty about endangering his informants through his research. "[An informant] said, 'I hope you haven't destroyed my life'. I said I didn't want to get people in trouble. I was scared for myself but not that scared. They are terrified all the time." He described how if his informants were captured by the secret police there would be very serious consequences for them. "There are prison camps... you can't graduate from school." He was particularly concerned for his translator: "If something happened to him I wouldn't be able to forgive myself. As far as I know he's still alright".

One student said she was made to feel guilty by her supervisor when he visited the field and expressed that she was not doing "proper" fieldwork. They had disagreed about where she should be spending her time in the field, and he wanted her to accompany him to a village several hours' journey away. She was just recovering from dengue fever and felt she was too weak to make the long Landrover journey and gruelling hike. "I was told that I wasn't a good anthropologist and that I wasn't doing proper ethnography. I was made to feel very guilty."

Abiona described how she felt guilty about the difficulties of her fieldwork, but had later realised this was because she had not been properly prepared for them. "People don't talk to you, and when they do talk to you they don't stay on topic. One day I went to [the fieldsite] and everyone had gone! You expect to go out there and just collect data... when these things happen you think that they are your fault. Actually, it's just that life is complicated and people have their own agendas. I thought it was my fault because I didn't understand that [the field] is a muddle."

\section{Harassed}

Sue and Ruth, both young white women, were harassed as they conducted fieldwork. Sue was bombarded with SMS messages from one man, and he was not dissuaded until she threatened to call the police. Ruth's harasser went house to house to find out where she lived, and waited outside her fieldwork site for hours to speak to her. Both women spoke with local friends about the problem. Sue was told that the man's behaviour was "very scary" and "not normal", and she became concerned. There had been stories in the news about stalkers at the time, and a young woman had recently been killed in another part of the country. She regretted her naivety in thinking that mentioning her boyfriend to informants would always be successful in deflecting romantic attention. Ruth also mentioned her boyfriend to deflect attention, and when they broke up halfway through fieldwork she felt vulnerable. She was told that her harasser's behaviour was just an extreme version of something that white women in her fieldsite had to put up with on a daily basis. "I wasn't sure if I was allowed to be freaked out or not. It might be 'normal' there, but it's not normal for me." 


\section{Homeless}

Several students had practical problems storing their possessions in the UK, finding appropriate accommodation in the field, or when they returned to the UK.

The breakdown of relationships left students with a variety of logistical and practical problems around housing. Several students had to recover possessions from former partners whom they had broken up with during fieldwork. Rozalina's parents broke up during her fieldwork, and her family home was sold, which also left her with a problem of storing her possessions.

Tracey had numerous difficulties with accommodation during her fieldwork. She described how these emerged partly because her project changed significantly during the first few months, partly because she was let down by various parties, and partly because of her own mistakes. She had to move more than four times during the year, and most of these moves were sudden, unanticipated and costly. She described having a stable, safe, decent place to live as one of the most important factors in enabling her to get her life and work back on an even keel. Elin, who had yet to start her fieldwork, said that finding affordable housing had been the biggest challenge of her preparations. "It sounds so stupid that this would have been the main problem... but it has been."

Kevser also had problems finding stable, safe, decent accommodation. When she first got to her fieldsite all the guesthouses were booked up, and she could not afford to stay at an expensive hotel. She went to a Lutheran hostel, "hoping they'd have some notion of charity, and would let me sleep on the floor." An act of kindness gave her a bed for a few nights, after which she spent a week or so at a newly vacated room of a guesthouse. She later met a young female anthropologist who put her up for about five months, but personal issues made that living arrangement untenable. Kevser was told it would be inappropriate to live with a family, and could not live in a settlement because she was told it would not be safe. She eventually found a small flat.

A number of non-British students described having difficulties feeling at home in the UK after fieldwork. Telma described how "returning [here, to the UK] has been difficult... lonely. I no longer have a place here. I have a profound sense of not being here." However, Euan, also an overseas student, could not wait to get out of his fieldsite and back to the UK. "I'd reached the end of my tether. I thought it was just awful and I wanted to get out of there. As soon as I got [to the UK], it was better. I knew it would be. I've never been so happy to be back [in the UK]."

\section{Paranoid}

For Euan, one of the major feelings he hoped to leave behind in the field was paranoia. His landlord in the field had been asked to spy on him. "My friends said my house was bugged. My whole sense of privacy went out the window... and it wasn't just paranoia - things happened. My facebook [page] was shut down, my hotmail account shut down. I heard the police were doing raids on every foreigner in the town." This had a major effect on his fieldnotes: "[The landlord] said I should erase everything I wrote... that I should just remember it and not write anything down." Euan described how strange he felt about it all, because in a way "nothing actually happened". There was never a raid and he was never directly threatened, but the possibility of what might happen was very stressful: "You know there is surveillance 
but you just don't know who or when or where. You assume danger in the broadest possible sense." Euan described how paranoia was a "default condition" of people in his fieldsite.

A number of other students also reported feeling paranoid. Students found it difficult to differentiate between issues they should justifiably be worried about, those they had no rational reason to worry about, and issues that were indicative of the kind of fieldsite they were working in - whose status as "truth" they could not be sure of. Many people described themselves as having significant psychological distress as they attempted to cope with their experiences.

\section{Pressured}

Tracey described feeling under pressure just before handing in her research proposal: "The day before the hand-in I got an email from my supervisor saying 'the thesis will do, but the proposal needs serious reworking' - after previously having said it was great! I stayed up all night until 4, and then got up again at $6 . .$. I have never handed anything in that I was so unhappy with." Her mother had booked a day at a health farm on the day of hand-in itself, further reducing the time Tracey had for work. "My period arrived at the health farm. My body completely collapsed."

Other students reported pressure during fieldwork itself. One person was just recovering from a bout of typhoid when her supervisor came to visit her in the field. He had brought several of his own informants with him, and said that they would all stay in her house. She was expected to provide food for them all, and told to take one of the informants around with her as a way to gather data. The supervisor eventually left, and his informants stayed with the student for a further week. "Eventually I had to ask them to leave. They thought I wasn't very hospitable. It was very uncomfortable."

Another student felt pressured to exert himself on fieldwork activities when he had only recently come out of hospital. There was a major ceremony in the village where he was working, which involved physical exertion throughout the night. He was too weak to partake for more than 20 minutes, and described his frustration at missing out on the event. His supervisor only put more pressure on him: "She was very disapproving that I hadn't stayed up all night. It was as if I wasn't doing a proper ethnography and my health was irrelevant."

Some students felt under pressure by their university departments to finish their $\mathrm{PhDs}$ quickly. One described how she was only supposed to do 12 months of fieldwork, and ended up doing 13 months "which wasn't really long enough". Incorporating language training in this time was difficult. Other students felt that their supervisors put pressure on them to write and present work quickly after finishing fieldwork.

Euan, Phuong, Ruth and Poppy all described being "interrogated" during fieldwork. Euan described how the local police would interrogate him for an hour each month. "She kept trying to catch me out on things. There were all these rules. My [language] wasn't good enough and she'd keep banging out [the rules]... boom boom boom." Phuong described being intensely questioned by one would-be informant, supposedly to ascertain whether he should give her a piece of information. "After an hour of interrogation he said he couldn't remember where it was!" Ruth's informants often presented agitated questions to her when she was hoping to relax with them socially: 
"In the end I had to make a rule... if I have a drink in my hand, you are only allowed to ask me three questions about my PhD."

\section{Regretful}

Whilst there were many times when students felt powerless, they also often felt deeply responsible for the difficulties they had. Many expressed regret about mistakes they had made in the field, and during their pre-fieldwork training.

One student described how her original research proposal had been borne of her exhaustion following her undergraduate studies: "I created this project because I needed a break. I was so tired after [my final exams]. I had this fantasy of [the fieldsite] being just me... chill... space." She described how she had "fucked up big time" with her research proposal.

As she fought to retrieve the process, she said she had made several other mistakes. She left for language training even though her funding body had regulated that she should stay for three months in the UK, after which things "rapidly fell apart". She spoke of her sense of culpability: "How did I make this so difficult?! I should have done what [the funding body] said. I shouldn't have been so obsessed. I should have calmed down. I don't know why [my university department] passed [my original research proposal]. I made this big fuss about coming back [to rewrite the unravelling proposal]!"

Margaret described her dissatisfaction with the fieldwork she had conducted. "I didn't use a very good methodology... I didn't do enough interviews... it was hard to get interviews but I should have persevered. So much was happening [in the fieldsite], I'd just be off following people... every day of notes is just [fragments]... I didn't take one thing and follow it, I just bumped into things and didn't pursue them. Now I'm dealing with reviewers of articles I've written, and they are all asking for data that I don't have. I sit completely paralysed thinking I have nothing to say. I have no authority at all." Reading the first draft of this study, another student said she felt similarly.

Margaret explained this failure was a direct result of not having understood how to do ethnography. "I kept bringing analysis into the notes. They are completely useless. There was no point in doing the analysis at the time - it just concealed from me how much I didn't know. I was jumping to conclusions and seeing patterns... I thought I'd collected data but I hadn't." Margaret described how her pre-fieldwork training had been dominated by a concern with theory, and feeling insecure about her professional identity, she had hidden behind this language which was familiar from her undergraduate studies. "The emphasis on theory really affected the way I did fieldwork. I needed an awareness of evidence - to understand that certain kinds of writing count as evidence, and certain kinds don't. The comments from reviewers are always about how the argument needs to be driven by ethnography. I needed to learn to produce the kind of description in the field that could then be used to produce analysis - and I didn't." A significant number of students reported feeling that they had not gathered enough data.

Some students expressed regret that they were not more assertive during fieldwork, either towards their informants or their supervisors. One person, however, felt she had been too assertive. Under the pressure of feeling that she was not getting good quality data, she pressed her informants to be more candid with her: "I did these pushy 
interviews because I was fed up with people not talking to me properly." Once, a woman tearfully asked her to stop the interview and refused to see the student again. "I left feeling really crappy. It was going too far."

\section{Silenced}

A significant number of students expressed feeling silenced when talking about fieldwork with their supervisors. There was a consensus that the need to maintain a "professional" relationship limited the extent to which they could speak candidly about their experiences. Students reported that they tended to play down difficulties in the field, and wherever possible show how they were going to make difficulties productive in their dissertations. "There are many things you want to say, and you can't say because it's not right. There are so many things you can't talk to your supervisor about." This was connected to issues of shame: "There are certain things you don't reveal to yourself, never mind your supervisor."

There was also evidence that some supervisors felt silenced themselves. One student's supervisor told her that she had known for months that her project was untenable, but "wanted [the student] to work it out for herself". One student had felt deeply let down by her supervisor's failure to reply to emails and complete basic paperwork, only to discover some months later that the supervisor had been diagnosed with cancer, and was recently bereaved himself.

Another student tried to make a formal complaint about their supervisor's conduct, and wanted to change to a different member of the faculty. Raising the matter with a senior department member, he was told that it would damage his career to make an issue of it. He was advised that he needed good relations with the supervisor because the academic circles they moved in were so small. The student described his vulnerability in the supervisor/supervisee relationship: "I need references from [the supervisor]... even now I haven't been able to ask. I feel like I have to go through very odd systems of post-docs... it's very hard to explain without making yourself seem difficult."

Telma had also had difficulties in her relationships with members of the department, and felt that the silence that surrounded these was unhelpful. She felt that "an unpleasant state of non-relation" had developed, and felt that there was some kind of repression involved. Without wanting to encourage people to talk behind one another's backs, she wished that the issues were out in the open: "I' $d$ rather people talked [about what happened] than not."

Many students remarked that fieldwork experiences themselves were surrounded by silence. There was dissatisfaction with the low amount of interaction between different $\mathrm{PhD}$ year groups. Some universities had seminars where a post-fieldwork student described their experience to pre-fieldwork students, whilst others had no such forum. The seminars that did exist were not seen as successful: "It's all so glossy... they just said they missed their family and their friends. It was so romantic." "People have to present themselves as professional so they won't tell you what really happened." This incentive for silence was evident in the process of interviewing students for this study. There was an acute fear of what might happen if the anonymising devices of this study were to fail. Speaking openly about the difficulties of fieldwork was seen as a profound risk to students' burgeoning reputations as academic professionals. 
Some students reported feeling they should not talk about how difficult they had found fieldwork because other people would perceive them as weak: "I felt it was all part of the rite of passage that people have to go through. [My fieldsite] was supposed to be so easy and civilised. I never felt able to say I was having a really hard time." Some compared themselves to others and felt they had not had very difficult experiences after all: "I came back and heard other people's stories and thought it was kind of nothing." Another described how she did not want to write in a "sensational" way: "I find myself censoring myself a lot, which I don't like. I just want people to understand the point of my research, not get swept up in all the sensation. Most of the time I don't talk about it... I only talk when people ask me about it."

One person decided to withdraw their material from this study. They explained that a key task of their writing-up had been working out how to incorporate and integrate their difficult fieldwork experiences into their own sense of self. Until they were farther along in this process, it was too difficult to have these experiences reflected in another piece of writing. However, they did ask for this comment itself to be included.

\section{Stressed}

Students had many stressful experiences on fieldwork. These had a serious impact on their minds and bodies.

The person who was supposed to meet Abiona at the airport did not turn up. She had been told that the airport she was flying into was the most dangerous in the world. "I hadn't changed money before passport control because I had been told you'd get a better rate at the cashpoint, and I was relying on this guy to take me there. Eventually I persuaded some women outside to give me some coins to make a phone call. It turned out he'd just forgotten about me."

Several students made discoveries in the field that could potentially have been very dangerous either to them or their informants (and which understandably cannot be described in any more detail in writing). Euan was very stressed out by everything that was happening. "I hadn't drunk for years and I started drinking again. It was a bad idea." Other people became very stressed upon discovering that malicious rumours were being spread about them. Some had strange phone calls, strange interviews or other strange occurrences that they struggled to make sense of.

Despite having already lived and worked in her fieldsite, and being well prepared for what she might face, Hafsah found fieldwork very stressful. "I spent my time getting kicked out from one place to another. It was very interesting and I'm glad I did it but I didn't have a nice time at all." She said that many of the skills she used to cope with the situation were those she had learned outside her academic training - when working for non-governmental organisations (NGOs) before she started her postgraduate study.

\section{Trapped}

Several students reported feeling trapped in certain situations. Euan's landlord scammed him out of money and would come into his house when he was out, but he was "stuck there". As Abiona's health deteriorated she came to find herself in increasingly difficult circumstances: "My sister had phoned the insurance company and they had asked if I'd been sick before. She said I'd been ill for a year, and they 
voided my insurance policy. I was still in negotiations with them when I went to the village. There was no way out of the village - the plane wasn't coming for another month. I realised I had to walk, and I was scared because I was deteriorating. I knew I had to get back to town to see a doctor. I found someone to help me with the walk. It should have been six hours and it ended up being ten. I suddenly had this realisation that I was really, really ill. It was nothing to do with laziness or my incapability to do proper fieldwork."

Students reported finding it difficult to let go of the traumas of fieldwork, because the writing-up process meant they were continually having to relive them: "I dread reading my notebooks because there are markers of all these feelings... it brings back all the emotions." Others felt that the only way they could escape the trauma of their experiences was to use it productively in their ethnographic writing. ${ }^{2}$

Those who were fairly far along in the writing-up process described how they had been successful in this: "I'm noting [a theme] coming up. This is of interest to me and it wouldn't have been if I hadn't gone through something palpable. It became a very embodied orientation. It filtered my themes; it made me empathetic and pricked up my ears to content and suffering which I wouldn't have noticed otherwise. One of the things I haven't confronted yet is the extent to which I'm prepared to recognise this in what I write. I really don't know." Looking through the interviews as a whole, there was a clear link between how far along in the writing-up process students were, and how comfortable they were describing their trauma and seeing it reflected in this study.

As difficulty was linked to intellectual productivity, students described being responsible for their own suffering - understanding it as a consequence of their ambition. Euan said: "I understood I had to do it. I never considered a different fieldsite... from the minute [I realised the importance of the fieldsite] I was obsessed by this place. It was like there was no other option. By the time [I started fieldwork] I'd grown up a lot and matured. I knew the realities of living there would be difficult, but you have to follow your desire."

\section{Uncomfortable}

Some students described being in uncomfortable environments, where the practicalities of life were very challenging.

Telma's discomfort, however, was mostly prompted by her efforts to retain her autonomy: "People are always trying to capture you as a person. I had to learn what was an acceptable response... how to guard people off without being rude." Phuong's landlord was often drunk, which made her feel very uncomfortable. She was also once pressured by the local Chief of Police, who was also drunk, and very persistent in his demands that she should come with him for an evening: "It was very dodgy. I was a bit uncomfortable because I was in the same hotel as him."

One student reported that the thoughtlessness of the department made her uncomfortable. She had won a prestigious funding award and this was mentioned over and over in front of her classmates. Teachers would single her work out as a good

\footnotetext{
${ }^{2}$ I relate to this sentiment myself, and was motivated to write this study partly in feeling that my ethnographic writing was held back by my own fieldwork trauma. Having written it though, I feel that we sometimes put too much pressure on ourselves in this regard.
} 
example for others, sparking resentment in other students. "It certainly didn't help [the $\mathrm{PhD}$ ] group relations!"

\section{Unprepared}

No post-fieldwork student, from any university, reported that the pre-fieldwork training course provided by their department was satisfactory: "Pre-fieldwork was absolutely fucking useless." "It was the worst course I've ever done." "The training is shit." "There was zero preparation for actual fieldwork."

The main criticism was that the training was too theoretical, and not practical enough. Post-fieldwork students from every university described feeling that they had not been sufficiently prepared for the technical, physical process of doing fieldwork and collecting data. Akanksha described how her course had failed to prepare her for the "nitty gritty": "You have an academic discussion but it doesn't really tell you what to do!" Some students found that they got better advice on fieldwork methods from family and friends than from their teachers. However, one student suggested that we should give up being "ready" for the field in advance: "No training, however practical it might be, can ever really prepare you [for fieldwork]. You only learn how to do fieldwork when you are doing fieldwork!"

Some departments had provided occasional classes on how to do interviews; others had done "practice" fieldwork sessions in the local area. Whilst they could point to some useful experiences, none of the post-fieldwork students were satisfied with the training course overall. Many described how it was simply designed around "jumping through hoops".

Students understood that funding bodies imposed some of these hoops on the training courses, and knew that the department was limited in the extent it could mitigate the inconvenience. Sometimes, however, they felt departments missed opportunities to ease the burden on students. For example, at one university the entire $\mathrm{PhD}$ cohort was compelled to take a course and four-hour examination in statistics, when it was only technically required of students who were funded by the Economic and Social Research Council (ESRC).

Some felt that the departments were deliberately not demonstrating practical approaches to fieldwork, so that students would make their own decisions and develop their own techniques in the field. No student whom I interviewed had ever been allowed to read the fieldnotes of a senior anthropologist, although there were rumours that this had once happened at a university department not included in this study.

Several students said that their pre-fieldwork viva was very theoretical, and did not interrogate their practical arrangements or technical preparation to do fieldwork. One student expressed his recognition of the challenge for departments: "The problem is that anthropology is the whole world - right!?" He suggested that $\mathrm{PhD}$ students should avoid imagining that they could learn everything they needed to learn for fieldwork from their supervisors, or from their pre-fieldwork training course.

Feeling under-prepared for fieldwork had serious consequences in the field. For Abiona, it meant that she was not clear about what activities in the field were important and necessary, and which ones she could cut out without seriously damaging her ethnography: "It was the fact that I didn't know how to do fieldwork, that was why I ended up working too hard. Now that I understand I can look after 
myself." Whilst acknowledging the problem that a project develops because of the data available, and so all data is potentially relevant for some project, she suggested that students needed to have more confidence in knowing whether or not certain fieldwork activities were important for the kind of project they were trying to do.

Maria felt under-prepared for fieldwork, and over-prepared for theoretical analysis. The examiners of her research proposal had been very impressed with her work: "I feel now that I'd been protecting myself by producing theory... this was just a defence mechanism which enabled them to tick the boxes." With their encouragement, she felt that everything would be fine in the field. She described how this led her to believe that she would not have to experience anything new: "I went into a slightly unthinking mode... I [did fieldwork activities and wrote notes], but I remember feeling quite bored. I should have been breaking down the things I already knew. I never managed it."

Euan stressed that his life before training had prepared him far more for fieldwork than the pre-fieldwork training itself. "I'd already lived [abroad] for three years in a remote area and... I had no illusions about going on fieldwork. I knew being isolated isn't anything nice and I knew it was going to be difficult." A number of others echoed this sentiment.

\section{Unsupported}

There was a great variation in how much support students expected, wanted and had from their supervisors. Some had negotiated a "hands-off" arrangement, whilst others were in close contact. Students had difficulties when the supervisors gave more or gave less than they expected - or when they were confused about how much support they could and should ask for.

One student felt that her supervisor was using flattery to evade responsibility for supporting her: "She always said to me, 'you are going to produce something brilliant'. In this very off-hand way. I never understood it - I think it served her well, the fact that she believed me to be competent meant that she wouldn't be needed."

In moments of distress, when they were feeling resentful and let down, some students described being angry and bewildered at the way their supervisors would deflect issues away from both themselves and the student. "He responded like an institution. He didn't deal with me as an individual... he just put on his cloak. I was very angry with him." "We never really talked about it, she just presented all the issues in the abstract - as if they had automatically had to be dealt with in certain ways because of what anthropology is like. I didn't know what to feel about it - I still don't."

Other students described how their supervisors took it personally when they tried to reframe their relationship. One student felt that his supervisor was being too interfering with his fieldwork and analysis. He tried to get a change in his supervision arrangements, and took advice to present the request as prompted by practical issues. His supervisor interpreted his request as an attack, and the student recalled how his supervisor said: "It's very upsetting for me. I feel that [another department member] is trying to steal you as a student."

Departmental politics affected supervisor-supervisee relationships in other ways. One student reported how her (relatively junior) supervisor had been "rapped over the knuckles" by senior members of the department, because the student had written a 
weak research proposal. The supervisor then became very demanding during the student's fieldwork - frequently asking for fieldwork reports and becoming very sceptical of the decisions the student made about how to do her ethnographic research.

Some students said that the main source of support for fieldwork came from close friends within their $\mathrm{PhD}$ cohort, rather than supervisors. Some said that the most important source of support during fieldwork was their informants. Others said they received critical help from their families, friends and partners.

Several students had technical problems in the administration of their funding. Some had their funding in the field suspended because of administrative errors. Some supervisors were not able to process paperwork on time, and there was variation in how successful back-up systems were in these circumstances. Some students had a second supervisor who could be a source of extra back-up; others "had" such a person but actually had no relationship with them. No department had provided a systematic map of who students could contact for support, and what they could ask of them in particular circumstances.

\section{Unwell}

Illness was a common problem in the field. Several people reported having a lot of headaches due to stress. Others were very tired. Students had experienced typhoid, malaria, dengue fever or other diseases common in tropical countries.

Several students said that they ignored the symptoms of their bodies: "My body had gone into overdrive... I was very ill. I wouldn't stop. I was on a complete mission." "I couldn't lift my hands to type, my legs were hurting... I was throwing up two or three times a day. It carried on for about seven months - and I just ignored it!”

Alone, unwell and in a strange place, it could be difficult to get treatment and support. Abiona had suffered two bouts of malaria, and was struggling to get conclusive diagnosis from doctors. "I was [in the fieldsite] and I was feeling faint and nauseous... I couldn't stand up. I actually crawled along the ground to [find help]."

\section{Questions for PhD students}

Experiences of fieldwork may provoke many different questions for the reader, but here are a selection that might be useful for pre-fieldwork $\mathrm{PhD}$ students to consider:

- If you were to feel alone, ashamed, bereaved, betrayed, depressed, desperate, disappointed, disturbed, embarrassed, fearful, frustrated, guilty, harassed, homeless, paranoid, regretful, silenced, stressed, trapped, uncomfortable, unprepared, unsupported, unwell, or something else, how would you cope?

- What is more important to you than your PhD? Is your health, your body, your relationships, or something else more important? How will you know if you are compromising too much?

- What is your worst case scenario for fieldwork, and for the rest of the $\mathrm{PhD}$ process? How would you cope with it? 
- What do you need to learn before you go on fieldwork? Is it reasonable to expect your supervisor or your pre-fieldwork training course to teach you this? In what other ways can you learn what you need to learn?

- Do you understand the difference between activities in the field that are crucial to gathering data, activities that are potentially useful, and activities that are irrelevant? For the project that you want to do, what kinds of activities might fit in each category? What evidence is there that you should not trust your own judgement on this issue?

- What can you ask of your supervisor, in what circumstances? Who else within the department can you ask for help? Are you clear about what you can expect from them? Are you clear about what kind of support you can seek from other people in your life?

- What are you trying to get out of your $\mathrm{PhD}$ research apart from a contribution to disciplinary knowledge? How should this impact upon your attempt to write an academic dissertation?

- Do you have an emergency plan? If something were to go wrong, do you have mechanisms in place to maximise your chances of getting help? What are the lines of communication between people in the field, your department, and your next of kin? If you were not able to seek help yourself, how could others do this for you?

\section{Supervisor dilemmas}

From the experiences of students, we might imagine that supervisors face a number of dilemmas:

\section{(1) Support versus independence}

Supervisors want to support and encourage their students as they undertake the challenges of fieldwork, which they will have faced themselves earlier in their careers. However, a $\mathrm{PhD}$ dissertation must be an independent contribution to knowledge, and supervisors may feel that they have to avoid supporting students in certain ways, over certain issues, in order to avoid unduly influencing their research process and professional development. How could supervisors know what kinds of difficulties they should try to help their students to cope with, and which ones they should leave them to deal with independently? How could they communicate their judgements on such issues to students, without making their students feel abandoned? How might the traumas that supervisors have experienced themselves impact on teaching and learning?

\section{(2) Autonomy versus guidance}

Supervisors are under pressure in many different ways as academic professionals, and many have other commitments and obligations besides supervising $\mathrm{PhD}$ students. It is critical for supervisors to guard their own autonomy, and to avoid becoming a source of all guidance on every issue regarding the $\mathrm{PhD}$ student's work. How can supervisors provide the critical guidance that $\mathrm{PhD}$ students need, without becoming overburdened themselves?

It is also critical for PhD students to develop and maintain autonomy as independent researchers, and to make their own decisions about the direction of their research projects. However, at the same time they need guidance from more experienced 
academics, and the supervisor is a vital conduit for this. Students may not always be aware of the guidance they need, and they may not always welcome the autonomy they are given. How could supervisors provide the guidance students need, without undermining their burgeoning autonomy? How could they help students feel ready to become autonomous themselves?

\section{(3) Authority versus communication}

Supervisors are in a position of authority. They are a source of professional references, funding validation, and are formally responsible for monitoring the student's progress at the university. If the student loses the supervisor's respect, or makes them feel ashamed or angry, the student will become very vulnerable. It may also be important for supervisors to maintain authority, so that the student accepts guidance which is in their long-term interests. However, communication is essential if the supervisor is to be aware of important issues in the student's work, and vice versa. If the student is not happy with the supervisor's teaching and has not communicated this to them, the supervisor may not know what is wrong. How could supervisors balance the critical need for authority and communication? How could supervisors frame the kinds of issues that they would like students to talk to them about? How could they foster an appropriate dialogue on the teaching needs of the student?

\section{Departmental dilemmas}

From the experiences of students, we might also imagine the dilemmas of academic departments:

\section{(1) Preparation versus flexibility}

Pre-fieldwork training needs to prepare students for the field, but it cannot prepare them for everything. Anthropological fieldwork needs to respond to the circumstances and issues that arise when research is in progress, and it is not possible to anticipate all eventualities. Academic departments need to help students to be flexible on fieldwork, but they also need to help them understand the academic consequences of the decisions they make. How could academic departments clarify what students should expect to learn from pre-fieldwork training, and what they should expect to learn for themselves? How could academic departments help students to make sound scholarly decisions with confidence?

\section{(2) Theory versus practice}

It is critical that students understand and engage with theoretical debates in the prefieldwork year, so that they are able to carve out a research problem that is cogent and valuable. However, students also need to understand the practicalities and techniques of fieldwork, so that they are able to gather evidence in the field. Confidence over the practical and technical issues of fieldwork enables students to be flexible, and take autonomous decisions about how they want their research to develop. How could academic departments improve pre-fieldwork training? How could they demonstrate some of the myriad techniques of fieldwork, and indicate their analytical consequences?

\section{(3) Requirements versus needs}

Many aspects of the pre-fieldwork year are required by funding bodies, and there are a variety of bureaucratic imperatives that must be satisfied before students can proceed 
to fieldwork. However, these requirements are not always aligned with the learning needs of students. Sometimes they are simply an inconvenience, and sometimes they positively work against the learning activities that students need to undertake before starting fieldwork. How could academic departments minimise the burdens that are placed on students in the pre-fieldwork year? How could they ensure that such burdens are not counter-productive? How could they ensure that pre-fieldwork training addresses learning needs, not just learning requirements?

The three academic departments of this study each had safety-nets in place in case of problems in the supervisor - supervisee relationships. Most students had a "second supervisor" or "advisor", who was formally responsible for providing additional support. However, in each of the departments there was reason to question whether these arrangements were working. How could university departments clarify what students should be able to ask of their second supervisors, or others in the department? If students have concerns about their supervisors, can they get assistance without undermining themselves?

\section{A recommendation}

In the course of doing this study, numerous ideas have developed to suggest how the difficulties in fieldwork might be made easier to cope with. From interviews with students, the most popular idea was a mentoring scheme, where post-fieldwork students would act as mentors for pre-fieldwork students.

This idea developed out of the observation that there is a fundamental limitation to the extent of support that can be provided by supervisors, or any member of the department, for $\mathrm{PhD}$ anthropologists. No matter how well they do their jobs, $\mathrm{PhD}$ anthropologists will always be reticent about revealing difficulty in fieldwork because they are worried that this will damage their fragile, emerging reputations as academic professionals. The supervisor-supervisee relationship is simply too important to risk burdening supervisors with candid disclosure of difficulty.

The mentoring scheme is premised on the idea that $\mathrm{PhD}$ students need support from people who understand ethnographic fieldwork, but who have as little power as possible over their professional careers. It is proposed that the mentor should be a post-fieldwork $\mathrm{PhD}$ student, who does not have a tenured position in any university department. They should, wherever possible, avoid having power over the mentee's academic development. For example, they should not be a person who could give references for the student or formally evaluate their progress. It would be important to carefully consider the training requirements and support available to mentors themselves.

Supervisors are given very little financial remuneration for the hours of dedicated work they invest in teaching $\mathrm{PhD}$ students. However, financial remuneration is one way of professionalising a relationship and establishing that it is a matter of duty, not good will. If mentors were to be remunerated on a similar scale to some supervisors, one faculty member in one department estimated that it would cost academic departments less than $£ 100$ per year, per student. A mentor would be able to do little more than help $\mathrm{PhD}$ students anticipate the kinds of difficulties they may face, and support them as they take responsibility for dealing with such difficulties. Still, the cost of administering such a scheme is low, considering the nature and extent of the difficulties $\mathrm{PhD}$ anthropologists face over fieldwork. 
Mentoring is one of myriad possibilities for reducing the difficulties of $\mathrm{PhD}$ anthropologists. Further opportunities exist for university departments, for supervisors and for students themselves.

\section{Acknowledgments}

I would like to thank all the students for participating in the study, and for doing so with such candour. I thank all the students, Jonathan Mair, Marilyn Strathern and Andrew Pollard for commenting on drafts, and the university departments for facilitating the study. Funding for the research was provided by the Higher Education Academy's Subject Network for Sociology, Anthropology, Politics (C-SAP). Particular thanks to my mum and dad, and to Cambridge Samaritans for supporting me during this work.

\section{About the author}

Amy Pollard wrote her $\mathrm{PhD}$ dissertation at the University of Cambridge on aid effectiveness and harmonisation in Indonesia. Her research interests include the social life of policy processes, development, institutional relationships and bureaucracy. She can be contacted at pollard.amy@googlemail.com. 